\title{
Deciphering Synsepalum dulcificum as an Arising Phytotherapy Agent: Background, Phytochemical and Pharmacological Properties with Associated Molecular Mechanisms
}

(Mentafsir Synsepalum dulcificum sebagai Agen Fitoterapi yang semakin Meningkat: Latar Belakang, Sifat Fitokimia dan Farmakologi dengan Mekanisme Molekul Berkaitan)

\author{
Jia Wer Ee, Appalaraju Velaga, Rhanye Mac Guad, Vetriselvan Subramaniyan, NeERaj Kumar \\ Fuloria, SHIVkanya Fuloria, KER WOON CHOY \& YUAN SENG WU*
}

\begin{abstract}
Medicinal plants with less side effects are paramount important for humankind to cure various ailments as compared to newly developed allopathic medicines. Synsepalum dulcificum Daniell (Sapotaceae), is well known as miracle fruits due to its distinctive taste-modifying property. This review aimed to discuss its recent reported pharmacological properties and associated molecular mechanisms as a novel phytotherapy agent. In addition, background, phytochemical analysis and toxicological studies were also discussed as the foundation and added values for this review. It was discovered that $\mathrm{S}$. dulcificum is endowed with various classes of phytochemicals, such as flavonoids, tannins, alkaloids and saponins. This review ravelled that $\mathrm{S}$. dulcificum is a potent medicinal plant associated with antioxidant, antidiabetic, antimicrobial, anticancer, anti-hyperuricemic, hepatoprotective, anti-hyperlipidaemic, and anticonvulsant activities, with less toxicity shown. Future research may explore further the corresponding phytochemicals, associated molecular mechanisms, toxicological and pharmacokinetic profile before subjecting to clinical testing.
\end{abstract}

Keywords: Miracle fruit; molecular mechanism; phytotherapy agent; Synsepalum dulcificum; therapeutic activity

ABSTRAK

Tumbuhan perubatan sangat penting bagi manusia untuk menyembuhkan pelbagai penyakit berbanding dengan ubat aloi yang baru dikembangkan kerana ia lebih selamat dengan kesan sampingan yang lebih rendah. Synsepalum dulcificum Daniell (Sapotaceae) terkenal sebagai buah ajaib kerana sifatnya yang mengubah rasa. Ulasan ini bertujuan untuk meninjau dan menguraikan sifat farmakologi yang dilaporkan baru-baru ini dan mekanisme molekul yang berkaitan sebagai agen fitoterapi baru. Selain itu, latar belakang, analisis fitokimia dan kajian toksikologi juga dibincangkan sebagai asas dan nilai tambah untuk ulasan ini. S. dulcificum didapati dikurniakan pelbagai kelas fitokimia, seperti flavonoid, tanin, alkaloid dan saponin. Ulasan ini membuktikan bahawa S. dulcificum adalah tumbuhan perubatan kuat yang memiliki aktiviti antioksidan, antidiabetik, antimikrob, antikanser, anti-hiperurikemia, hepatopelindung, antihiperlipidemia dan antikonvulsan dengan ketoksikan yang kurang ditunjukkan. Penyelidikan masa depan boleh mengkaji fitokimia, mekanisme molekul yang berkaitan, profil toksikologi dan farmakokinetik sebelum menjalani ujian klinikal.

Kata kunci: Agen fitoterapi; aktiviti terapi; buah keajaiban; mekanisme molekul; Synsepalum dulcificum

\section{INTRODUCTION}

Right from creation, all parts of a plant containing active phytochemicals have become a source of phytomedicine (Ramakrishnan et al. 2020; Soladoye \& Chukwuma 2012). For many years, medicinal plants are deemed as appropriate sources utilised in traditional medicine for the treatment of various diseases (Yin et al. 2004). According to World Health Organisation (WHO) statistics, 80\% of people worldwide utilise traditional treatment (Wang et al. 2012). Interestingly, $60 \%$ of the US Food and Drug Administration (FDA)-approved drugs, from the year 1984 to 1994, were mostly isolated from plants (Kumar et al. 2012). In fact, most allopathic medications can cause multiple side effects and not cost-effective. People truly 
believe that natural plant products possess lesser side effects, safer, less likely to cause dependency and do not lead to alteration of biochemical and physiological pathways (Mahady 2001; Rahmani \& Aldebasi 2015). As such, the use of plant-based products seems to be more reliable as compared to allopathic products.

Synsepalum dulcificum Daniell, which belongs to the Sapotaceae family, has been discovered as one of the medicinal plants. It is a native shrub in West-Central Africa and tropical West (Lim 2013). The attractive point of $S$. dulcificum falls on its unique ability to alter the tongue's reception of sour taste into the sweet taste, owing to the presence of glycoprotein miraculin in the berries. Given this extraordinary yet wonderful property, it has been known as a miracle fruit, miracle berry or magic berry (Swamy et al. 2014). Inglett et al. (1965) are the first group of researchers to initiate the study on miracle fruits, in the process of searching a natural sweetener to replace cyclamate and saccharin in the research centre. They found that miracle fruit was potentiated to be a natural sweetener. Hitherto, this natural sweetener is still well known and on-demand among diabetes patients and dieters in Japan. Additionally, miracle fruit has also been accepted by the FDA for use as a food additive (Small \& Catling 2006). It is also used as a natural food colourant, because it is rich in anthocyanins pigment that can form orange-red colour in sugar solutions or carbonated beverages (Buckmire \& Francis 1978).

Over the years, $S$. dulcificum has been used as a traditional remedy for the treatment of not limited to diabetes, malaria, stomachache, obesity, anaemia, and prostate ailments (Oumorou et al. 2010). Nevertheless, its traditional applications have been recorded primarily in local herbal books or just been passed down verbally from one generation to the next (Bhatia et al. 2014). The medicinal usage of $S$. dulcificum is paramount important as compared to its culinary purpose; thus, it is crucial to exploit this further as it has been reported with many promising therapeutic efficacies. The crude extracts of $S$. dulcificum have exhibited a wide spectrum of pharmacological properties in last decade, including antidiabetic (Dioso et al. 2016; Han et al. 2019; Obafemi et al. 2017, 2019), antioxidant (Cheng et al. 2015; Du et al. 2014; Han et al. 2019; Inglett \& Chen 2011; Shi et al. 2016), anticancer (Lu et al. 2014; Seong et al. 2018), antimicrobial (Wasoh et al. 2018), anti-hyperuricemia (Shi et al. 2016), hepatoprotective (Akinmoladun 2016), cholesterollowering (Huang et al. 2020) and anticonvulsant (Jeremiah et al. 2015). Further investigations have unveiled that $S$. dulcificum is endowed with various phytochemicals, which may potentiate for reported pharmacological properties (Awotedu \& Ogunbamowo 2019a; Njoku et al. 2016; Osabor et al. 2016).

$S$. dulcificum is of great interest, as evidenced by comprehensive studies conducted by different researchers in the recent years. Thus, this paper presents a detailed review of the pharmacological properties of $S$. dulcificum, the possible underlying mechanisms of actions and classes of phytochemicals involved. Withal, it could be used as a supporting reference for future research work, formulation development, monograph preparation, drug design, nano-formulation and may act as a backbone to develop safe and effective alternative therapeutic agent in the future. Besides, it also highlights the possible gaps and areas requiring further research works of this plant.

\section{BACKGROUND OF S. dulcificum DISTRIBUTION}

West-Central Africa and tropical West are where $S$. dulcificum naturally grows and develops (Lim 2013). It is likely covered the areas in Ghana, Benin, Cameroun, Nigeria, and Congo (Achigan-Dako et al. 2015). Afterwards, this species has been distributed to many countries in Southeast Asia, as well as Australia and the United States of America (Lim 2013).

\section{CULTIVATION AND COLLECTION}

S. dulcificum grows well in a warm, partially shady, wet to humid and frost-free environment. It prefers welldrained acidic soils, with $\mathrm{pH}$, falls between 4.5 and 5.8. This species is unable to stand for alkaline soil condition and waterlogging. Therefore, to achieve the required acidity level, equal parts of pine bark and Canadian acid peat can be mixed (Achigan-Dako et al. 2015; Lim 2013). Most of the $S$. dulcificum plants are seed-based cultivation, but the seedlings grow slow at nursery stage (Duke \& duCellier 1993). Precisely, there are two growth phases for $S$. dulcificum (Joyner 2006). The first phase is corresponding to the first four years whereas the second phase beginning from four years old onwards (AchiganDako et al. 2015). Typically, a one-year-old plant is only 5 to $7.5 \mathrm{~cm}$ tall, and it needs to spend three to four years to reach 35 to $50 \mathrm{~cm}$ tall. Starting from four years old, the plant achieves maturity and grows more rapidly (Joyner 2006).

Both flowering and fruiting of $S$. dulcificum happen two to three times every year (Oumorou et al. 2010). The small white flower blossoms from April to May, July to August and November to December, while the fruit is obtainable in May, August, October and from December to February. If the plant is free from disruption, for instance, windy weather, birds and overharvesting 
by humans, the plant can bear fruit for 30 to 60 days. Large-scale production of this berry is restricted due to the growth of seedling is extremely recalcitrant (Chen et al. 2009). A mature $S$. dulcificum plant can produce around 12 to $15 \mathrm{~kg}$ of ripped fruits yearly. However, the yield is varied and depends on the plant age, habitat and branching (Achigan-Dako et al. 2015).

\section{TRADITIONAL USAGE AND MEDICINAL VALUES}

S. dulcificum is formerly famous for its culinary purposes, owing to its amazing capabilities of turning the sour taste into a pleasantly sweet taste. Given this taste-modifying property, the fruit pulp of $S$. dulcificum is used to make the acidulated maize bread (kankies) and stale tastier in West Africa. Besides, the Africans also use miracle fruits to sweeten their beer (pito) and palm wine (Inglett \& May 1968). In Rajasthan, the leaves of $S$. dulcificum are mixed with Bajra, which is a cereal commonly used in India to prepare bread, whereas, in Tamil Nadu, the leaves are cooked and served as vegetables.

From other perspectives, S. dulcificum also has a lot of folkloric medicinal uses. In Benin, the fresh leaves are generally used for the treatment of diabetes, enuresis, hyperthermia, and malaria; the almonds, on the other hand, are used to treat anaemia, obesity and stomach ache (Oumorou et al. 2010). Likewise, the bark is involved in the treatment of prostate ailments, whereas the root serves to treat tuberculosis and cough. In India, $S$. dulcificum is made into a poultice and applied to the abdomen for relieving abdominal discomfort (PMP 2018). In Tokyo, since the Japanese sellers promoting low-calories desserts, they have initially made all dessert items tasteless and bitter, but after the addition of miracle fruits, the cake and ice cream become sweet and more palatable. Therefore, the miracle fruits are well known among diabetes patients and dieters in Japan (Chen et al. 2009).

It has been reported that taste alterations (dysgeusia) in patients who received chemotherapy treatment are common, but there is no existing of associated conventional therapy (Soares et al. 2010). The abnormal tastes subsequently resulted in the loss of appetite, malnutrition and compromised the treatment response (Soares et al. 2010). Thus, a pilot study was conducted to determine the ability of miracle fruit supplement in improving the chemotherapy-associated taste alteration, thereby increasing the nutritional intake (Wilken \& Satiroff 2012). The results showed that all participants had positive taste change after taking the supplement.
Apart from the edible purposes and usage for folkloric treatment, $S$. dulcificum is also useful in making agricultural tools. Its branches can be used to make rake and hoe, while its twigs are served in the making of toothbrush (Oumorou et al. 2010).

\section{MORPHOLOGICAL CHARACTERS}

S. dulcificum is a small shrub that grows slowly and reaches up to $4 \mathrm{~m}$ in height when it is fully matured. The tree can be cone or pyramidal in shape. Due to it stays green throughout the year; thus, it is the so-called evergreen tree (Achigan-Dako et al. 2015).

It has deep green and glabrous leaves that are in the ratio of length to width in $2: 1$, which it is around 3.1 to $3.8 \mathrm{~cm}$ wide, with the length range from 4.3 to $7.5 \mathrm{~cm}$ (Achigan-Dako et al. 2015). Besides, it has been reported that the fresh leaves of $S$. dulcificum are cylindrical in shape and small in size, with a bitter taste and faint scent (Awotedu \& Ogunbamowo 2019a). The surface of the leaves is observed to be fractured and non-glandular. Meanwhile, the composition of leaves is simple, entire and opposite. The leaves have a smooth margin and pinnate venation, with an obtuse shape apex (Awotedu \& Ogunbamowo 2019a). Moreover, the leaves base are observed to be unequal, and the texture is smooth but slightly hard. Additionally, the petiole is relatively short. Likewise, the foliage is dense and clustered at the ends of the slender branchlets (Inglett \& May 1968).

Its fruits are bean shape and bright red when ripe, in which it is around $1 \mathrm{~cm}$ wide with the length range from 2 to $3 \mathrm{~cm}$. Each fruit has only seed covered by a thin layer of pulp (Achigan-Dako et al. 2015; Inglett \& May 1968). The small, creamy-white and bisexual flowers are generally solitary or in small clusters and always pointing downward (Achigan-Dako et al. 2015).

\section{PHYTOCHEMICAL ANALYSIS}

Phytochemicals are the lead compounds that are responsible for the induction of a pharmacological activity conferred by any plants (Bonam et al. 2018). Thus, it is crucial to identify the phytochemistry profile of a plant crude extract. For $S$. dulcificum, different parts have been reported to contain various primary and secondary metabolites. For instance, alkaloid, flavonoid and tannin were present in the petroleum ether leaf extract of S. dulcificum (Osabor et al. 2016). However, they were absent in the aqueous leaf extract of $S$. dulcificum. Apart from that, the phytochemical screening showed that saponin was present in both the aqueous extract of leaves 
and roots. Besides, polyphenols and cardiac glycosides were also detected in all experimental set-ups, including the petroleum ether and aqueous extracts of $S$. dulcificum leaves and roots (Osabor et al. 2016).

The pulp of $S$. dulcificum has been claimed to contain alkaloid, saponin, flavonoid, tannin, glycoside, protein, carbohydrate and reducing sugar, while the acidic compound, resin, fat or oils were absent (Njoku et al. 2016). Most recently, alkaloid, saponin, flavonoid, tannin, glycoside, and phenolic compounds were reported to be present in the whole fruits and leaves of S. dulcificum, while anthraquinone was only detected in the leaves (Awotedu \& Ogunbamowo 2019b).

\section{PHARMACOLOGICAL STUDIES}

Intriguingly, $S$. dulcificum has demonstrated a wide range of pharmacological activities as stated in different literatures, which are discussed in the following subsections and summarized in Table 1 . These activities are believed due to the presence of various active phytochemicals distributed throughout different parts of S. dulcificum.

\section{ANTIOXIDANT ACTIVITY}

Several studies have been conducted on S. dulcificum to determine its potential antioxidant activity. For instance, the ethanolic extracts of $S$. dulcificum skin contained the highest phenolic content (43.96\%) as compared to pulp and seeds, which could be due to the flavonoid content $(81.32 \%)$ (Inglett \& Chen 2011). On the other hand, the DPPH assay result showed that the skin and pulp possessed nearly similar antioxidant activity and higher than that of seeds. Despite that, the seeds still contributed to $49.45 \%$ of free antioxidant activity (Inglett \& Chen 2011). All three extracts could be a great source targeted for antioxidant effect.

Another study indicated that the methanolic extracts of $S$. dulcificum flesh showed high antioxidant activity (96.3\%), causing them to be good reducing agents and contributed to significant DPPH free radical scavenging activity (Du et al. 2014). Meanwhile, the seed extract demonstrated relatively lower antioxidant activity (54.3\%) as compared to flesh extract. Besides, the flesh extract gave $32.5 \%$ of antioxidant activity as evaluated by ABTS assay, in which its activity was approximately two-fold of the seed extract (18\%). Similarly, the flesh extract also attributed to greater reduction percentage as compared to seed extract in FRAP assay (Du et al. 2014).

Besides, acetic acid buffer and pure ethanol were also used to screen for antioxidant components of $S$. dulcificum seeds (Cheng et al. 2015). Briefly, DPPH antioxidation strength and ABTS free radical scavenging were found to be more than $70 \%$, while the ferrous ions chelating effect attained $80 \%$. Although low total phenolic content was obtained in pure ethanol extracts, both DPPH and FRAP assays still demonstrated potent antioxidant activity (Cheng et al. 2015), suggesting that S. dulcificum seeds are an excellent multi-antioxidant source.

Furthermore, the antioxidant effects of S. dulcificum by using ethyl acetate, butanol, hexane and water as solvents were also identified (Shi et al. 2016). The results indicated that the ethyl acetate extract had relatively higher phenolic and flavonoid compounds, which contributed to its potent antioxidant activity as evaluated in the DPPH and ABTS free radical scavenging capabilities and power reduction (Shi et al. 2016). In the same year, the antioxidant defense of $S$. dulcificum methanolic fruit extract has also been reported (Akinmoladun 2016). After administering the rats with 50 to $200 \mathrm{mg} / \mathrm{kg}$ for 14 days, the glutathioneS-transferase activity in the serum was significantly $(p<0.05)$ increased. In fact, the oxidative stress marker, malondialdehyde levels were also decreased in rats treated with 25 to $100 \mathrm{mg} / \mathrm{kg}$ groups. However, the increased level was observed in the rats treated with $200 \mathrm{mg} / \mathrm{kg}$, which was supported by decreased glutathione levels and activities of catalase glutathione hepatic glutathione peroxidase $(p<0.05)$. These findings suggest that 50 to $100 \mathrm{mg} / \mathrm{kg}$ of extracts may exhibit antioxidant defence, whereas the pro-oxidative effects may occur in high concentration.

Recently, a study showed that the total phenolic and total flavonoid content in the ethanolic skin-pulp extract of $S$. dulcificum was found higher than the seed extract (Han et al. 2019). Additionally, the result also showed that $1 \mathrm{~g} / \mathrm{mL}$ of skin-pulp extract demonstrated the highest DPPH effect of $52.60 \%\left(\mathrm{IC}_{50}=0.9 \mathrm{mg} /\right.$ $\mathrm{mL}$ ), which was nearly five-fold higher than the seed extract $\left(\mathrm{IC}_{50}=6.3 \mathrm{mg} / \mathrm{mL}\right)$ (Han et al. 2019). This claim is supported by the fact that an agent with higher antioxidant capacity is indicated by higher scavenging activity with lower $\mathrm{IC}_{50}$ values (Brand-Williams et al. 1995).

\section{ANTIDIABETIC ACTIVITY}

There was a study determined the hypoglycaemic effects of fruit and leaf extracts of S. dulcificum and compared with the positive control, metformin (Dioso et al. 2016). Galloxan was used to induce the type 2 diabetes 
mellitus in 25 albino rats, from which these rats were divided into five groups to receive different treatments. For instance, positive control with metformin, 50\% fruit extract, $50 \%$ leaf extract, $100 \%$ fruit extract and 100\% leaf extract. The results suggested that 50 and $100 \%$ of both fruits and leaves exhibited the same effectiveness in reducing blood glucose levels in albino rats. Likewise, all subjected concentrations significantly reduced the blood glucose levels in a similar pattern, as shown by metformin (Dioso et al. 2016).

Besides, the antidiabetic activity of methanolic and flavonoid-rich leaf extracts was evaluated using type 2 diabetic Wistar albino rats (Obafemi et al. 2017). Sixtythree rats were divided into nine groups, with group 1 as normal control, group 2 as diabetic control, group 3 to 7 were administered with $30 \mathrm{mg} / \mathrm{kg}$ methanolic leaf extract, $60 \mathrm{mg} / \mathrm{kg}$ methanolic leaf extract, $30 \mathrm{mg} / \mathrm{kg}$ flavonoidrich leaf extract, $60 \mathrm{mg} / \mathrm{kg}$ flavonoid-rich leaf extract and $5 \mathrm{mg} / \mathrm{kg}$ glibenclamide, respectively. While group 8 and 9 composed of healthy rats administered with $60 \mathrm{mg} /$ $\mathrm{kg}$ methanolic leaf extract and $60 \mathrm{mg} / \mathrm{kg}$ flavonoid-rich extract, respectively. Interestingly, the groups treated with glibenclamide and extracts significantly decreased the blood glucose levels as compared to the diabetic control group. Their blood glucose levels were incomparable with normal control (Obafemi et al. 2017).

Given the potent antidiabetic property of $S$. dulcificum leaf extracts in rats, the possible underlying molecular mechanisms were also investigated by Obafemi et al. (2019). The in vivo results showed that both methanolic and flavonoid-rich leaf extracts attenuated the levels of $\mathrm{HbA1c}$, serum interleukin (IL)-6 and tumor necrosis factor alpha (TNF- $\alpha$ ) in the diabetic rats. Contrarily, the extracts-treated groups showed an elevation in serum insulin level and hepatic hexokinase activity. Furthermore, both extracts inhibited $\alpha$-amylase and $\alpha$-glycosidase in vitro. The docking analysis further demonstrated that chlorogenic acid, quercetin and caffeic acid could bind to glucokinase with a strong affinity. In summary, this study identified that increased insulin production, decreased inflammation and inhibition of carbohydrate metabolising enzymes could be the possible mechanisms underlying the antidiabetic activity of S. dulcificum.

Another recent study evaluated the antidiabetic effects of seed and fruit flesh ethanolic extracts of $S$. dulcificum (Han et al. 2019). The fruit extract, seed extract ( 1 to $1000 \mu \mathrm{g} / \mathrm{mL}$ ) or the positive control, metformin (1 $\mathrm{mM}$ ), was tested on the differentiated mouse myoblast C2C12 cells with or without the presence of insulin. The MTT cell viability assay showed that 1 to $500 \mu \mathrm{g} /$
$\mathrm{mL}$ of both extracts and $1 \mathrm{mM}$ of metformin were nontoxic to the cells. For $\mathrm{C} 2 \mathrm{C} 12$ cells receiving insulin treatment, 50 to $500 \mu \mathrm{g} / \mathrm{mL}$ of fruit extract effectively enhanced glucose uptake to 162.2 to $205.0 \%$. Besides, the seed extract ( 10 to $100 \mu \mathrm{g} / \mathrm{mL}$ ) could promote the glucose uptake to $183.3-205.3 \%$. Nevertheless, the seed extract at $500 \mu \mathrm{g} / \mathrm{mL}$ could not significantly increase the uptake of 2-Deoxy-2-[(7-nitro-2,1,3-benzoxadiazol-4-yl) amino]-D-glucose (2-NBDG), which may attribute to its higher cytotoxicity. Comparatively, the fruit extract at $500 \mu \mathrm{g} / \mathrm{mL}$ demonstrated higher 2-NBDG uptake than metformin, regardless of the administration of insulin. The treatment of fruit extract also upregulated the expression of insulin receptor in $\mathrm{C} 2 \mathrm{C} 12$ cells (Han et al. 2019).

\section{ANTICANCER ACTIVITY}

The anticancer property of $S$. dulcificum has been discovered in the recent decade. For instance, the cytotoxic effects of ethanolic and methanolic extracts of S. dulcificum fruits, leaves and stems were investigated on human colon cancer HCT-116 and HT-29 cells (Seong et al. 2018). The evaluation was performed using qRTPCR and PrestoBlue ${ }^{\circledR}$ cell viability assay. The results indicated that the methanolic stem, ethanolic stem and ethanolic berry extracts exhibited cytotoxic effects on HCT-116 and HT-29 cells. The $\mathrm{IC}_{50}$ values determined for these three extracts were of similar potency as the positive chemotherapeutic agent, bleomycin $(33.57 \mu \mathrm{g} /$ $\mathrm{mL}$ ) in HCT-116 cells. Interestingly, the $\mathrm{IC}_{50}$ values were significantly lower than that of bleomycin $(25.24 \mu \mathrm{g} /$ $\mathrm{mL}$ ) in HT-29 cells. Additionally, all extracts did not have a cytotoxic effect on monocytic leukaemia THP-1 cells and normal human dermal HDFn fibroblasts. It was further discovered that the cytotoxic effect was due to apoptosis induction associated with increased expression of c-fos and c-jun genes (Seong et al. 2018).

In another study, 68 essential oils were isolated from $S$. dulcificum leaves using steam distillation, and only 44 components were identified successfully (Lu et al. 2014). The main essential oils derived from $S$. dulcificum leaves were spathulenol, limonene, diisoostyl phthalate, dibutyl phthalate, palmitic acid and linalol. The MTT assay showed that the leaves-derived essential oil reduced the viability of human myelogenous leukaemia K562 cancer cells in a concentration-based manner, with the $\mathrm{IC}_{50}$ value of $13.5 \mathrm{mg} / \mathrm{L}$ (Lu et al. 2014).

\section{ANTIMICROBIAL ACTIVITY}

To date, there is only one preclinical study investigating the potential antimicrobial activity of $S$. dulcificum 
(Wasoh et al. 2018). They investigated the antibacterial effect of $S$. dulcificum ethanolic and methanolic leaf extracts on Listeria monocytogenes and compared the treatment efficacy with that induced by Morus alba and Strobilanthes crispus. The results showed that $S$. dulcificum possessed lower antibacterial activity as compared to $M$. alba regardless of the age of the leaves or extraction solvents used. Besides, all leaf extracts of $S$. crispus did not show antibacterial activity on $L$. monocytogenes. The methanolic mature leaf extract of S. dulcificum exhibited significant antibacterial activity at $284.74 \mathrm{~mm}^{2} / \mathrm{mL}$ as compared to the young leaf extract at $159.06 \mathrm{~mm}^{2} / \mathrm{mL}$. Similarly, the ethanolic mature and young leaf extracts of $S$. dulcificum exhibited antibacterial activity at 271.47 and $232.59 \mathrm{~mm}^{2} / \mathrm{mL}$, respectively (Wasoh et al. 2018).

\section{ANTI-HYPERURICEMIA ACTIVITY}

S. dulcificum fruit extract has also been discovered in one preclinical study possessing potent uricemia-reducing potential (Shi et al. 2016). One of the mechanisms in causing hyperuricemia is due to the production of cellular reactive oxygen species by xanthine oxidase, a key enzyme in purine metabolism, that is actively involved in uric acid formation (Shi et al. 2016). For instance, the above study used various solvents, such as water, butanol, ethyl acetate and hexane to prepare $S$. dulcificum fruit extracts (Shi et al. 2016). It was interesting to take note that all extracts significantly reduced the serum uric acid levels and blocked the activity of xanthine oxidase in vitro and inhibited oxidative stress induced by monosodium urate in RAW264.7 macrophages. Among the extracts, the butanol extracts were showed to significantly reduced oxonic acid potassium saltinduced hyperuricaemia in Institute of Cancer Research (ICR) mice by suppressing the accumulation of serum uric acid and activating hepatic xanthine oxidase. The therapeutic effect of butanol extracts was incomparable with the positive control, allopurinol, suggesting that this extract could be a potential anti-hyperuricemia agent. Besides, the water extract of $S$. dulcificum exerted greater inhibition on xanthine oxidase than allopurinol. The induction of adverse effects in kidney and liver, alteration of serum creatinine and blood urea nitrogen (BUN) levels were not seen in the subjected mice after seven days of investigation.

\section{HEPATOPROTECTIVE ACTIVITY}

The hepatoprotective effect of $S$. dulcificum has also been discovered recently (Akinmoladun 2016). The researcher investigated the effect of methanolic fruit extract on hepatotoxicity markers in trichloroacetic acidinduced hepatotoxic Wistar albino rat. Experimentally, the rats were administered with 25 to $200 \mathrm{mg} / \mathrm{kg}$ of extracts for 14 days. After the treatment period, the total bilirubin levels in the treated rats were decreased significantly as compared to the untreated rats $(\mathrm{p}<0.05)$. The results further showed that extract at $50 \mathrm{mg} / \mathrm{kg}$ could suppress serum alkaline phosphatase (ALP) and alanine aminotransferase (ALT) levels but not for aspartate aminotransferase (AST) (Akinmoladun 2016).

\section{ANTI-HYPERLIPIDAEMIC ACTIVITY}

Lately, a study claimed that $S$. dulcificum also possessed the therapeutic effect in lowering the cholesterol levels in hamsters fed with a high-cholesterol control diet (Huang et al. 2020). They divided the hamsters into six groups. Each group was fed with, either control diet or experimental diets consisting of $2 \%$ ethanolic leaf extract, $2 \%$ aqueous leaf extract, $2 \%$ ethanolic seed extract, $2 \%$ aqueous seed extract or $2 \%$ dry pulp, for six weeks. At the end of the study, the results demonstrated that experimental diets containing ethanolic and aqueous extracts of leaves and seeds suppressed the elevation of total plasma cholesterol. Similarly, triacylglycerol and non-high-density lipoprotein (HDL)-cholesterol levels were also decreased after treatment, but HDLcholesterol levels were not affected. Comparatively, it was notable that ethanolic seed extract of seeds showed the most significant effect, while dry pulp did not exhibit any cholesterol-reducing effect. Owing to the potency of ethanolic seed extract in decreasing plasma cholesterol concentration, column chromatography was further applied to isolate and identify the underlying phytochemicals. The significant cholesterol-reducing effect of ethanolic seed extract is, at least in part, contributed by two triterpenoids (lupeol acetate and $\beta$-amyrin) as they could suppress the total cholesterol by 15-20\% (Huang et al. 2020).

\section{ANTICONVULSANT ACTIVITY}

In addition to other pharmacological properties, the anticonvulsant potential of $S$. dulcificum has also been discovered, which is contributed by its aqueous seed extract (Jeremiah et al. 2015). The seizure effect in mice was induced by pentylenetetrazole (PTZ), strychnine, and maximal electroshock (MES) tests. The results showed that the aqueous extract at $0.3 \mathrm{mg} / \mathrm{kg}$ gave $16.67 \%$ protection against mortality and $33.33 \%$ at a higher dose $(1.2 \mathrm{mg} / \mathrm{kg})$. Comparatively, the reference drug, 
diazepam $(1 \mathrm{mg} / \mathrm{kg})$ showed $100 \%$ protection against PTZ-induced convulsion and mortality. In strychnineinduced seizure mice, all tested doses gave 33.33\% protection against mortality in comparison to $66.67 \%$ given by diazepam $(5 \mathrm{mg} / \mathrm{kg})$. Besides, the onset of convulsion was found similar in all tested groups. In MES-induced seizure mice, all the subjected doses could not protect the mice from the tonic hind-limb extension. However, at least, the recovery time to convulsant was significantly reduced (Jeremiah et al. 2015). Collectively, the findings confirm the anticonvulsant activity of $S$. dulcificum aqueous seed extract. The anticonvulsant potential of other solvent extract and parts are deemed to be evaluated for its maximum effect.

\section{TOXICOLOGICAL STUDIES}

Most studies have investigated the medicinal and nutritional values of $S$. dulcificum. In fact, significantly fewer studies have been conducted to evaluate its toxicity or toxic-related biochemical effects. Nonetheless, a study carried out an acute toxicity test on albino rats treated with methanol pulp extract of $S$. dulcificum (Chinelo \& Uzoma 2015). Interestingly, the results showed that there was no rat died after orally administering the pulp extract at doses up to $5000 \mathrm{mg} / \mathrm{kg}$. Besides, biochemical parameters analysis showed that extract at $100 \mathrm{mg} /$ $\mathrm{kg}$ significantly $(\mathrm{p}<0.05)$ lowered the serum levels of bilirubin, ALT, and glucose after 14 days. However, the serum levels of ALP, AST, albumin and globulin were not significantly different between 14- and 28-day studies. The histopathological examination further showed that the $S$. dulcificum methanolic pulp extract did not affect normal liver architecture at 100, 200 and $500 \mathrm{mg} / \mathrm{kg}$. In addition, another study also performed an acute toxicity test on the $S$. dulcificum aqueous seed extract by using Lorke's method (Jeremiah et al. 2015). From the results, all mice died in all experimental doses $(5,10,20,100$ and $1000 \mathrm{mg} / \mathrm{kg}$ ). However, extract at $2.5 \mathrm{mg} / \mathrm{kg}$ did not cause any death. It was further detected that the $\mathrm{LD}_{50}$ was $3.54 \mathrm{mg} / \mathrm{kg}$ via the intraperitoneal route of administration (Jeremiah et al. 2015).

TABLE 1. Pharmacological studies of $S$. dulcificum

\begin{tabular}{|c|c|c|c|c|c|}
\hline $\begin{array}{l}\text { Pharmacological } \\
\text { activity }\end{array}$ & $\begin{array}{l}\text { Type of } \\
\text { model }\end{array}$ & Part of plant & Solvent used & Phytochemical & Reference \\
\hline Antioxidant & $\begin{array}{l}\text { In vitro; } \\
\text { in vivo }\end{array}$ & $\begin{array}{l}\text { Skin; pulp; skin- } \\
\text { pulp; seed; flesh; } \\
\text { fruit }\end{array}$ & $\begin{array}{l}\text { Ethanol; methanol; } \\
\text { sodium acetate } \\
\text { buffer; ethyl acetate; } \\
\text { hexane; aqueous }\end{array}$ & $\begin{array}{l}\text { Phenols; flavonoids; } \\
\text { condensed tannins; ascorbic } \\
\text { acid; epicatechin; gallic acid; } \\
\text { ferulic acid; syringic acid; } \\
\text { rutin; quercetin; myricetin; } \\
\text { ellagic acid; kaempferol; } \\
\text { delphinidin glucoside; } \\
\text { malvidin glucoside; lutein; } \\
\alpha \text {-tocopherol; } \alpha \text {-tocotrienol; } \\
\quad \gamma \text {-tocopherol }\end{array}$ & $\begin{array}{l}\text { Cheng et al. (2015); } \\
\text { Du et al. (2014); Han } \\
\text { et al. (2019); Inglett } \\
\text { \& Chen (2011); Shi } \\
\quad \text { et al. (2016); }\end{array}$ \\
\hline Antidiabetic & $\begin{array}{l}\text { In vitro; } \\
\text { in vivo }\end{array}$ & $\begin{array}{l}\text { Fruit; leaf; skin- } \\
\text { pulp; seed }\end{array}$ & Ethanol; methanol, & $\begin{array}{l}\text { Phenols; flavonoids; } \\
\text { condensed tannins; gallic } \\
\text { acid; catechin; rutin; } \\
\text { quercetin; quercitrin; } \\
\text { chlorogenic acid; luteolin; } \\
\text { ferulic acid }\end{array}$ & $\begin{array}{l}\text { Dioso et al. (2016); } \\
\text { Han et al. (2019); } \\
\text { Obafemi et al. } \\
\text { (2017); Obafemi et } \\
\text { al. (2019) }\end{array}$ \\
\hline Anticancer & In vitro & Fruit; leaf; stem & Ethanol; methanol & $\begin{array}{l}\text { Spathulenol; limonene; } \\
\text { diisoostyl phthalate; dibutyl } \\
\text { phthalate; palmitic acid; } \\
\text { linalol }\end{array}$ & $\begin{array}{l}\text { Lu et al. (2014); } \\
\text { Seong et al. (2018) }\end{array}$ \\
\hline Antimicrobial & In vitro & Leaf & Ethanol; methanol & $\mathrm{N} / \mathrm{A}$ & $\begin{array}{l}\text { Shi et al. (2016); } \\
\text { Wasoh et al. (2018) }\end{array}$ \\
\hline $\begin{array}{l}\text { Anti- } \\
\text { hyperuricemia }\end{array}$ & $\begin{array}{l}\text { In vitro; } \\
\text { in vivo }\end{array}$ & Fruit & $\begin{array}{l}\text { Ethyl acetate; } \\
\text { butanol; hexane; } \\
\text { aqueous }\end{array}$ & Phenols; flavonoids & \\
\hline Hepatoprotective & In vivo & Fruit & Methanol & $\begin{array}{l}\text { Flavonoids; tannins; steroids; } \\
\text { cardiac glycosides }\end{array}$ & Akinmoladun (2016) \\
\hline $\begin{array}{l}\text { Anti- } \\
\text { hyperlipidaemic }\end{array}$ & In vivo & Leaf; seed; pulp & Ethanol; aqueous & Lupeol acetate; $\beta$-amyrin & Huang et al. (2020) \\
\hline Anticonvulsant & In vivo & Seed & Aqueous & N/A & $\begin{array}{l}\text { Jeremiah et al. } \\
\qquad(2015)\end{array}$ \\
\hline
\end{tabular}




\section{CONCLUSION AND Future PERSPECTIVES}

S. dulcificum is associated with various folkloric medicinal usage and can improve chemotherapyassociated taste alteration, thus, increasing the nutritional intake of cancer patients. It is also used as a food additive, food colourant, and natural sweetener.

Chemically, is endowed with different classes of phytochemicals. Considering its medicinal background, this review ravelled that $S$. dulcificum is highly associated with antioxidant and antidiabetic followed by anticancer, antimicrobial, anti-hyperuricemia, hepatoprotective, anti-hyperlipidaemic, and anticonvulsant activities. The deciphered pharmacological properties have proposed that $S$. dulcificum could be a natural therapeutic agent to combat different diseases. Nonetheless, most studies investigating antioxidant, antimicrobial and anticancer potentials of $S$. dulcificum are limited to in vitro findings. Thus, in vivo studies should be evaluated to well-establish its therapeutic profile. Additionally, further studies are required to examine the possible underlying mechanisms of some pharmacological properties. As for now, the associated mechanisms are only identified for antioxidant activity by regulating antioxidant enzyme; and decreasing pro-inflammatory cytokines and inhibiting carbohydrate-metabolising enzymes for antidiabetic activity. Interestingly, S. dulcificum is considered safe for consumption as showing low toxicity in vivo. However, its toxicological profile is limited to certain solvent extracts of particular parts, and the pharmacokinetic data is unavailable. Based on this review, it discovered that no preclinical study has been conducted on $S$. dulcificum barks and flowers for their pharmacological effects.

Given the fruits of $S$. dulcificum contributing potent pharmacological properties, its large-scale production is another issue to be considered as they require four years to reach maturity and fruiting. This situation may reduce the opportunities for scientific research and development. To ensure the sustainable use of miracle fruits, attention in intensifying the knowledge on horticultural practices is necessary to increase fruit production for supporting more research fields.

Collectively, this review paper provides comprehensive information on the background, phytochemical analysis, pharmacological properties and toxicology profile of $S$. dulcificum. Given the economic and non-toxic properties of $S$. dulcificum, as well as their promising preclinical treatment outcomes, further investigation of the potential of other parts or their derived phytochemicals and associated molecular mechanisms should be encouraged, in order to isolate, identify and evaluate their benefits. Future studies should also focus on evaluating the safety, toxicity and pharmacokinetic profile of $S$. dulcificum before subjecting it to the clinical setting.

\section{ACKNOWLEDGEMENTS}

This work was supported by the Fundamental Research Grant Scheme (Grant No. FRGS/1/2019/SKK10/ MAHSA/03/1) and MAHSA University research grant (Grant No. RP165-05/19).

\section{REFERENCES}

Achigan-Dako, E.G., Tchokponhoué, D.A., N'Danikou, S., Gebauer, J. \& Vodouhè, R.S. 2015. Current knowledge and breeding perspectives for the miracle plant Synsepalum dulcificum (Schum. et Thonn.) Daniell. Genetic Resources and Crop Evolution 62(3): 465-476.

Akinmoladun, A.C. 2016. Effect of Synsepalum dulcificum berry extracts on oxidative stress and hepatotoxicity indices, following subacute administration in normal rats. Futa Journal of Research in Sciences 1: 167-177.

Awotedu, O.L. \& Ogunbamowo, P.O. 2019a. Pharmacognostic and physicochemical profile of the leaves of Synsepalum dulcificum (Schumach. \& Thonn.) Daniell. International Journal of Agriculture, Forestry and Fisheries 7(2): 12-17.

Awotedu, O.L. \& Ogunbamowo, P.O. 2019b. Nutritional, antinutritional and phytochemical profile of the leaves and fruits of Synsepalum dulcificum (Schumach. \& Thonn.) Daniell. American Journal of Biological Chemistry 7(3): 53-59.

Bhatia, H., Sharma, Y.P., Manhas, R.K. \& Kumar, K. 2014. Ethnomedicinal plants used by the villagers of district Udhampur, J\&K, India. Journal of Ethnopharmacology 151(2): 1005-1018.

Bonam, S.R., Wu, Y.S., Tunki, L., Chellian, R., Halmuthur, M.S.K., Muller, S. \& Pandy, V. 2018. What has come out from phytomedicines and herbal edibles for the treatment of cancer? ChemMedChem 13(18): 1854-1872.

Brand-Williams, W., Cuvelier, M.E. \& Berset, C. 1995. Use of a free radical method to evaluate antioxidant activity. $L W T$ Food Science and Technology 28(1): 25-30.

Buckmire, R.E. \& Francis, F.J. 1978. Pigments of miracle fruit, Synsepalum dulcificum, schum, as potential food colorants. Journal of Food Science 43(3): 908-911.

Chen, C.Y., Wu, P.Y., Huang, T.S., Lin, C.W., Li, Y.C., Chou, R.H., Chang, H.W. \& Wang, H.M. 2009. The sour tastemodifying protein (miraculin), tyrosinase inhibitors and antioxidants from Synsepalum dulcificum. Current Nutrition \& Food Science 5(3): 172-179.

Cheng, F.Y., Huang, S.T., Lin, M.L. \& Lai, J.T. 2015. Polyphenol measurement and antioxidant activity of miracle fruit. International Journal of Chemical Engineering and Applications 6(3): 211-214. 
Chinelo, C. \& Uzoma, N.O. 2015. Effect of methanol extract of Synsepalum dulcificum pulp on some biochemical parameters in albino rats. Journal of Coastal Life Medicine 3(3): 233240.

Dioso, M.K.M., Satsatin, D.C.A. \& Ching, J.A. 2016. Hypoglycemic effects of Synsepalum dulcificum (Schumach. and Thonn.) Daniell (MiracleBerry) fruit and leaf extracts on the blood glucose level of albino rats. Der Pharmacia Letter 8(14): 104-108.

Duke, J.A. 1993. CRC Handbook of Alternative Cash Crops. Boca Raton: CRC Press.

Du, L., Shen, Y., Zhang, X., Prinyawiwatkul, W. \& Xu, Z. 2014. Antioxidant-rich phytochemicals in miracle berry (Synsepalum dulcificum) and antioxidant activity of its extracts. Food Chemistry 153: 279-284.

Han, Y.C., Wu, J.Y. \& Wang, C.K. 2019. Modulatory effects of miracle fruit ethanolic extracts on glucose uptake through the insulin signaling pathway in $\mathrm{C} 2 \mathrm{C} 12$ mouse myotubes cells. Food Science \& Nutrition 7(3): 1035-1042.

Huang, W., Chung, H.Y., Xuan, W., Wang, G. \& Li, Y. 2020. The cholesterol-lowering activity of miracle fruit (Synsepalum dulcificum). Journal of Food Biochemistry 44(5): 1-12.

Inglett, G.E. \& Chen, D. 2011. Contents of phenolics and flavonoids and antioxidant activities in skin, pulp, and seeds of miracle fruit. Journal of Food Science 76(3): 479482.

Inglett, G.E. \& May, J.F. 1968. Tropical plants with unusual taste properties. Economic Botany 22(4): 326-331.

Inglett, G.E., Dowling, B., Albrecht, J.J. \& Hoglan, F.A. 1965. Taste modifiers, taste-modifying properties of miracle fruit (Synsepalum dulcificum). Journal of Agricultural and Food Chemistry 13(3): 284-287.

Jeremiah, O.J., Ilesanmi, O.R. \& Ige, M.M. 2015. Evaluation of the anticonvulsant potential of aqueous fraction of Synsepalum dulcificum seed extract in mice. European Journal of Medicinal Plants 9(3): 1-8.

Joyner, G. 2006. The miracle fruit. In Quandong Magazine of the West Australian Nut and Tree Crop Association, edited by Scott, P. West Australia: West Australian Nut and Tree Crop Association Subiaco. p. 15.

Kumar, D.R.N., Cijo George, V., Suresh, P.K. \& Ashok Kumar, R. 2012. Cytotoxicity, apoptosis induction and anti-metastatic potential of Oroxylum indicum in human breast cancer cells. Asian Pacific Journal of Cancer Prevention 13(6): 2729-2734.

Lim, T.K. 2013. Synsepalum dulcificum. In Edible Medicinal and Non-Medicinal Plants: Volume 6, Fruits edited by Lim, T.K. Netherlands: Springer. pp. 146-150.

Lu, S.L., Liu, H., Chen, G.Y., Han, C.R. \& Zang, W.X. 2014. Chemical composition of leaf essential oil of Synsepalum dulcificum and evaluation of its antibacterial and antitumoral activities in vitro. Chemistry and Industry of Forest Products 34(1): 121-127.

Mahady, G.B. 2001. Global harmonization of herbal health claims. The Journal of Nutrition 131(3): 1120S-1123S.
Njoku, N.E., Ubbaonu, C.N., Alagbaoso, S.O., Agunwa, I.M. \& Eluchie, C.N. 2016. Proximate, anti-nutritional and phytochemical composition of the yellow variety of the Synsepalum dulcificum (miracle fruit) berry. American Journal of Food Science and Technology 4(4): 102-108.

Obafemi, T.O., Olaleye, M.T. \& Akinmoladun, A.C. 2019. Antidiabetic property of miracle fruit plant (Synsepalum dulcificum Shumach. \& Thonn. Daniell) leaf extracts in fructose-fed streptozotocin-injected rats via antiinflammatory activity and inhibition of carbohydrate metabolizing enzymes. Journal of Ethnopharmacology 244(112124): 1-8.

Obafemi, T.O., Akinmoladun, A.C., Olaleye, M.T., Agboade, S.O. \& Onasanya, A.A. 2017. Antidiabetic potential of methanolic and flavonoid-rich leaf extracts of Synsepalum dulcificum in type 2 diabetic rats. Journal of Ayurveda and Integrative Medicine 8(4): 238-246.

Osabor, V.N., Etiuma, R.A. \& Ntinya, M.U. 2016. Chemical profile of leaves and roots of miracle fruits (Synsepalum dulcificum). American Chemical Science Journal 12(1): 1-8.

Oumorou, M., Dah-Dovonon, J., Aboh, B.A., Hounsoukaka, M. \& Sinsin, B. 2010. Contribution a' la conservation de synsepalum dulcificum: re'ge'ne'ration et importance socioe' conomique dans le de' partement de l'oue'me' (Benin). Ann. Sci. Agron. 14(1): 101-120.

Philippine Medicinal Plants (PMP). 2018. Miracle fruit, Synsepalum dulcificum (Schumach. \& Thonn). http://www. stuartxchange.org/MiracleFruit. Accessed on 13 September 2020.

Rahmani, A.H. \& Aldebasi, Y.H. 2015. Potential role of Carica papaya and their active constituents in the prevention and treatment of diseases. International Journal of Pharmacy and Pharmaceutical Sciences 8(1): 11-15.

Ramakrishnan, P., Loh, W.M., Gopinath, S.C.B., Bonam, S.R., Fareez, I.M., Guad, R.M., Sim, M.S. \& Wu, Y.S. 2020. Selective phytochemicals targeting pancreatic stellate cells as new anti-fibrotic agents for chronic pancreatitis and pancreatic cancer. Acta Pharmaceutica Sinica B 10(3): 399-413.

Seong, J., Oyong, G. \& Cabrera, E. 2018. Synsepalum dulcificum extracts exhibit cytotoxic activity on human colorectal cancer cells and upregulate $c$-fos and $c$-jun early apoptotic gene expression. Asian Pacific Journal of Tropical Biomedicine 8(3): 173-178.

Shi, Y.C., Lin, K.S., Jhai, Y.F., Lee, B.H., Han, Y., Cui, Z., Hsu, W.H. \& Wu, S.C. 2016. Miracle fruit (Synsepalum dulcificum) exhibits as a novel anti-hyperuricaemia agent. Molecules 21(2): 1-11.

Small, E. \& Catling, P.M. 2006. Blossoming treasures of biodiversity. Biodiversity 7(3-4): 37-46.

Soares, H.P., Cusnir, M., Schwartz, M.A., Pizzolato, J.F., Lutzky, J., Campbell, R.J., Beaumont, L., Eton, D., Stonick, S. \& Lilenbaum, R. 2010. Treatment of taste alterations in chemotherapy patients using the "miracle fruit": Preliminary analysis of a pilot study. Journal of Clinical Oncology 28(15_suppl): e19523. 
Soladoye, M.O. \& Chukwuma, E.C. 2012. Quantitative phytochemical profile of the leaves of Cissus populnea Guill. and Perr. (Vitaceae) â an important medicinal plant in central Nigeria. Archives of Applied Science Research 4(1): 200-206.

Swamy, K.B., Hadi, S.A., Sekaran, M. \& Pichika, M.R. 2014. The clinical effects of Synsepalum dulcificum: A review. Journal of Medicinal Food 17(11): 1165-1169.

Wang, C.Z., Calway, T. \& Yuan, C.S. 2012. Herbal medicines as adjuvants for cancer therapeutics. The American Journal of Chinese Medicine 40(4): 657-669.

Wasoh, H., Tajuddin, S., Halim, M., Mohd-Hairul, A.R., Sobri, M.Z.M., Lajis, A.F.B., Yusof, M.T. \& Ariff, A.B. 2018. Antibacterial activity of Synsepalum dulcificum leaf extract against Listeria monocytogenes and its comparison with Strobilanthes crispus and Morus alba. Journal of Bio-Science 25: 73-75.

Wilken, M.K. \& Satiroff, B.A. 2012. Pilot study of "miracle fruit" to improve food palatability for patients receiving chemotherapy. Clinical Journal of Oncology Nursing 16(5): E173-177.

Yin, X., Zhou, J., Jie, C., Xing, D. \& Zhang, Y. 2004. Anticancer activity and mechanism of Scutellaria barbata extract on human lung cancer cell line A549. Life Sciences 75(18): 2233-2244.

Jia Wer Ee \& Appalaraju Velaga

Department of Medicinal Chemistry

Faculty of Pharmacy

MAHSA University

42610 Jenjarom, Selangor Darul Ehsan

Malaysia

Rhanye Mac Guad

Department of Biomedical Science and Therapeutics

Faculty of Medicine and Health Science

Universiti Malaysia Sabah

88400 Kota Kinabalu, Sabah

Malaysia
Vetriselvan Subramaniyan

Department of Pharmacology, School of Medicine

Faculty of Medicine, Bioscience and Nursing

MAHSA University

42610 Jenjarom, Selangor Darul Ehsan

Malaysia

Neeraj Kumar Fuloria \& Shivkanya Fuloria Faculty of Pharmacy

AIMST University

08100 Bedang, Kedah Darul Aman

Malaysia

Ker Woon Choy

Department of Anatomy

Faculty of Medicine

Universiti Teknologi MARA

47000 Sungai Buloh, Selangor Darul Ehsan

Malaysia

Yuan Seng $\mathrm{Wu}^{*}$

Centre for Virus and Vaccine Research

School of Medical and Life Sciences

Sunway University

47500 Subang Jaya, Selangor Darul Ehsan

Malaysia

Yuan Seng Wu*

Department of Biological Sciences

School of Medical and Life Sciences

Sunway University

47500 Subang Jaya, Selangor Darul Ehsan

Malaysia

*Corresponding author; email: sengwu_21@yahoo.com

Received: 25 November 2020

Accepted: 19 May 2021 